\title{
STEAM EDUCATION AT MASTER LEVEL
}

\section{María de Miguel Molina, Daniel Catalá Pérez, Ángel Peiró Signes, Marival Segarra Oña}

\author{
Universitat Politécnica de València (SPAIN)
}

\begin{abstract}
This work presents the Innovation and Improvement Learning Project "Applying STEAM strategies in the Social Sciences and Arts areas by means of a Service-learning methodology" that aims to facilitate the acquisition of the Science, Technology, Engineering, Arts and Maths competences of Master students in the Universitat Politécnica de València (UPV) by means of a service-learning focus. An interdisciplinary group of seven lecturers work in an own model that latter could be also applied to other Master and Bachelor Programs. By now, we have developed a competence sheet for each STEAM competence that could be applied in any subject that would like to work on it. To achieve these competences by a holistic approach, we also relate them to the UPV transversal competences and to the United Nations Sustainable Development Goals. The final objective is that any program could cover all the STEAM competences to add value to the students' learning. The first results show that, putting all these concepts together, we compel the students to propose creative solutions that could help organizations as well as individuals.
\end{abstract}

Keywords: STEAM competences, higher education, creativity, learning by doing.

\section{INTRODUCTION}

More than STEM competences, some authors have highlighted the value that an Arts\&Design competence can give to the students' curricula [1] what leads to the STEAM competences.

On the other hand, the Service-learning methodology gives the possibility of learning by doing and, at the same time, it can represent a community and environmental improvement [2]. Moreover, this community benefit is related to the United Nations Sustainable Development Goals. According to Batlle [3], service-learning "is a method for linking the social engagement with the learning of contents, skills, aptitudes and values. Learning to be competent by being useful to others". This kind of outside activities let the students to apply their knowledge to a real situation, improving other skills such as communication, active participation, creativity and others [4].

We propose the following learning goals for our Master students, but they could also be applied to a Bachelor level:

- To be able to establish hypothesis and measurable results (Science).

- To give evidences and register the process using some technology tools that let to contrast if some changes have occurred (Technology).

- To apply decision-making methods to compare different alternatives (Engineering).

- To propose creative solutions that could have a social impact (Arts\& Design).

- To evaluate their proposal cost and future benefits (Maths).

At present, two Master programs are involved: Business Management, Products and Services (MGEPS) and Conservation and Restoration of Cultural Assets (MCRBC). As we can observe, when we started our project some of the STEAM competences were already covered but not others (Table 1):

Table 1. Comparative of actual STEAM competences.

\begin{tabular}{|l|c|c|c|c|c|}
\hline & $S$ & $T$ & $E$ & $A$ & $M$ \\
\hline MGEPS & $\mathrm{X}$ & & $\mathrm{X}$ & & $\mathrm{X}$ \\
\hline MCRBC & & $\mathrm{X}$ & & $\mathrm{X}$ & \\
\hline
\end{tabular}

Source: own elaboration. 
Therefore, our aim is to cover all the STEAM competences in each Master Program and, if we test it successfully, to extend them to other Bachelor subjects and programs.

\section{METHODOLOGY}

Batlle proposes different steps when we want to develop a service-learning process [3]. They are distributed in three parts of a process: preparation, development and evaluation, and they comprise different stages.

- Preparation: idea/challenge, alliances/stakeholders and planning the project.

- Development: team working, performance and ending.

- Multi-evaluation: own, peers and stakeholders.

Even if our principal aim is to cover all the STEAM competences, we think that learning by doing and, moreover, offering new solutions for a better society is a convenient way to better involve our students. In a first step, we are developing different competence sheets, according to each professor's experience and background, to give basic information on how to apply each STEAM competence and how to evaluate it. The template of the competence sheet is showed in Figure 1. It is provided in Spanish and English as we have both type of subjects.

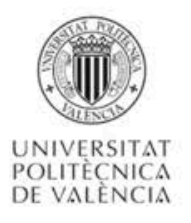

STEAM

INNOVATION AND IMPROVEMENT LEARNING PROJECT

\begin{tabular}{|l|l|}
\hline COMPETENCE & \\
\hline PROFESSOR & \\
\hline OBJECTIVE & Depending on the competence \\
\hline $\begin{array}{l}\text { OUTSIDE ACTIVITIES } \\
\text { PROPOSED FOR SERVICE- } \\
\text { LEARNING }\end{array}$ & Brief examples (around 3) \\
\hline $\begin{array}{l}\text { GENERAL QUESTIONS FOR } \\
\text { THE STUDENTS TO } \\
\text { EVALUATE THE } \\
\text { COMPETENCE } \\
\text { APPLICATION }\end{array}$ & $\begin{array}{l}\text { Questions related to the competence that could be } \\
\text { used in different subjects }\end{array}$ \\
\hline $\begin{array}{l}\text { UPV CROSS-DISCIPLINARY } \\
\text { COMPETENCES }\end{array}$ & Relation with these UPV competences \\
\hline $\begin{array}{l}\text { SUSTAINABLE } \\
\text { DEVELOPMENT GOALS }\end{array}$ & $\begin{array}{l}\text { Maximum 5 SDGs that could be worked in relation to } \\
\text { this competence }\end{array}$ \\
\hline
\end{tabular}

* The Project STEAM, coordinated by Professor Maria de Miguel, is compound by professors from the Faculty of Business Administration and the Faculty of Fine Arts, and its objective is that the students will be able to apply STEAM strategies (Science, Technology, Engineering, Art\&Design, Maths) in order to develop Service-Learning outside activities that could be applied in the community.

Figure 1. STEAM competences sheet. Source: own elaboration.

As it is observed in Figure 1, we relate the STEAM competences with two other groups. The first one is the UPV transversal competences. These cross-disciplinary competences represent a dynamic combination of knowledge, comprehension, abilities and aptitudes [5,6]. Their aim is to provide general competences to the students such as practical thinking, problem-solving, team working, leadership, ethics, communication, critical thinking, lifelong learning, time management, and so on.

On the other hand, we seek to link STEAM competences with Sustainable Development Goals [7], taking into account that we have a service-learning focus. We want our students to be aware that the SDGs "recognize that ending poverty must go hand-in-hand with strategies that build economic growth and address a range of social needs including education, health, social protection, and job opportunities, while tackling climate change and environmental protection". Therefore, we value all the activities that could help to improve the communities' way of life and sustainability. 
The competence sheets are brief in order to facilitate their application to any subject; thus, they are 1-2 pages and they are filled in a comprehensible and general language.

Therefore, the methodology proposed, as shown in Figure 2, highlights the importance of STEAM competences, working them from a service-learning point of view, and linking them to UPV transversal competences and SDGs. This methodology involves to cover three important points, adapting Battle's methodology:

a) Idea/challenge: which is the object of study (an organization, a firm, a community or a group of individuals) and which are the social objectives that we aim to achieve, depending on the subject,

b) Performance: what are the solutions that we propose, taking into account the competences and SDGs involved, and

c) Multi-evaluation: how the solutions will affect people and/or the environment.

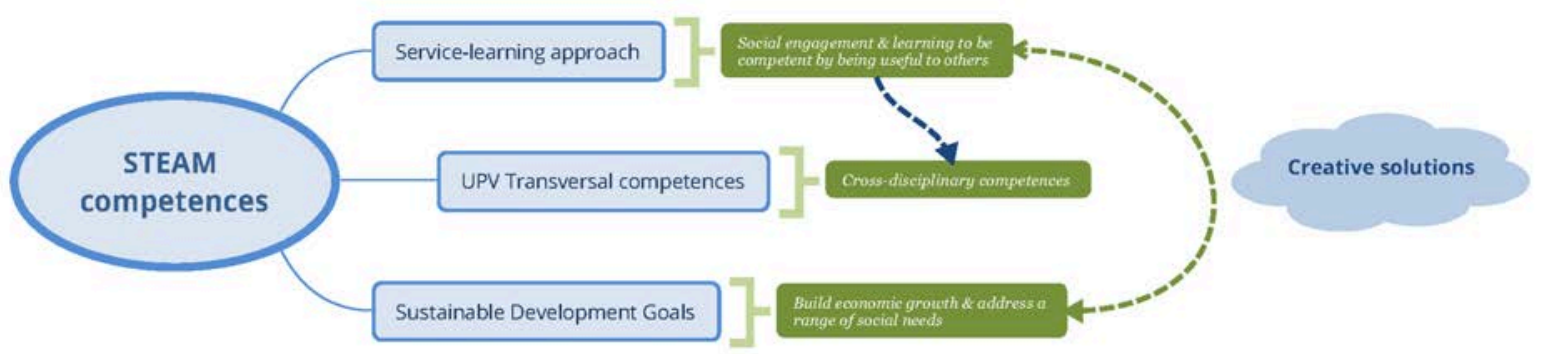

Figure 2. Methodology proposed to work on STEAM competences.

Source: own elaboration.

\section{RESULTS}

In a first step, we have completed all the competence sheets and we have applied them focusing on some subjects of the first semester of both Master programs. In this preliminary phase, we are testing their application and then we have no concluding results yet.

As an example, professor Peiró has developed the competence sheet 'Maths', with the learning goal of evaluating a proposal cost and its future benefits. As an outside activity for the subject 'Managerial University-Companies Knowledge Transfer' (MGEPS), with an approach of "being useful for others" [3], he recommends to visit a start-up and study a present problem to solve. The students, in small groups and with real data, analyse the problem and propose improvements in the process that are evaluated in terms of costs and benefits.

To evaluate the competence, he adds some questions that could be asked to the students:

- Did the work require the use of mathematical skills?

- Did you require assistance from the teacher to propose or solve the calculations included in the work?

- In the work, what level of challenge were the mathematical calculations?

- What level of obstacles did you encounter during the completion of the work related to the mathematical approach and calculations?

- How important was the activity in your opinion to improve your understanding and calculation of costs and benefits of a work?

The activity can be related to two UPV cross-disciplinary competences: 'analysis and problem solving' and 'practical and applied thinking'. The first one is defined as "to analyse and solve problems effectively, identifying and defining the significant elements that constitute them" while the second one consists of "to apply theoretical knowledge and establish the process to follow to achieve certain objectives, carrying out experiments and analysing and interpreting data to draw conclusions" [5].

Moreover, we ask the students to focus on some SDGs which compel them to think of creative solutions. The competence 'Maths' can be linked to three SDGs [7]: Economic Growth (8: "to create the conditions that allow people to have quality jobs that stimulate the economy while not harming the environment"), 
Infrastructure and industrialization (9: "Technological progress is the foundation of efforts to achieve environmental objectives, such as increased resource and energy-efficiency. Without technology and innovation, industrialization will not happen, and without industrialization, development will not happen") and Sustainable consumption and production (12: "doing more and better with less, involving everyone from producer to final consumer").

The same activity could be adapted to other subjects, maybe working with different kind of organisations, but following the same scheme.

\section{CONCLUSIONS}

The Project "Applying STEAM strategies in the Social Sciences and Arts areas by means of a Servicelearning methodology" will be running the next two courses and its aim is that the students will be able to develop all the STEAM competences in their Master Programs. Furthermore, we help the students to notice the links among them, the UPV transversal competences and the sustainable development goals. The synergies among them can add value to their curricula and improve their creativity. Organizations and firms demand not only knowledge but also soft skills (Wu-Pong et al., 2013) [8] and working on STEAM can promote creativity together with rationalization [9].

As far as we see, STEAM have been worked in a preliminary and high school level but they have been less developed in higher education. But, having the opportunity of studying in a technical university, with students from different backgrounds and possible synergies among the instructors, we have the chance of covering all STEAM competences.

At this stage of the project, we cannot present concluding results but we have already completed the competence sheets and we are testing them in order to apply each one in different Master subjects where they could be missed. In this case, we have pre-tested the competence 'Maths' in order to check if the competence sheet proposed could be applied to the Master subjects. The first results show that it is feasible to apply the activity proposed to different subjects, adding some changes. Moreover, we provide a simple structure that can be applied by any instructor with few changes.

This will be a new challenge for the project researchers who are members of two Innovation and Quality Education Teams of the UPV: 'Reality Baths: towards a visible, responsible and innovative learning' and 'Experiential Learning Group'. Both teams focus and objectives give value to the project as we have experience in outside service-learning activities. However, we have not directly worked on the synergies that could give us an opportunity for working competences that we are not used to, such as creativity for Management or Maths for Arts.

\section{ACKNOWLEDGEMENTS}

This work has been developed within the project "Applying STEAM strategies in the Social Sciences and Arts areas by means of a Service-learning methodology", conducted by Professor María de Miguel Molina, and with the support of the Universitat Politécnica de València (Science Education Institute, ICE).

Moreover, Prof. de Miguel belongs to the team 'Reality Baths: towards a visible, responsible and innovative learning', coordinated by Prof. V. Santamarina, and Prof. Peiró and Prof. Segarra belong to the team 'Experiential Learning Group', coordinated by Prof. Peiró.

\section{REFERENCES}

[1] Innobasque, “¿De qué hablamos cuando hablamos de STEAM?”, Innobasque, 2016. Retrieved from https://www.innobasque.eus/microsite/escuela_innovacion/article/de-que-hablamos-cuandohablamos-de-steam/

[2] Senate and House of Representatives of the United States of America, "National and Community Service Act", National Service, 2009. Retrieved from https://www.nationalservice.gov/sites/default/files/page/Service_Act_09_11_13.pdf

[3] R. Batlle, "Aprendizaje-Servicio", Roser Batlle, 2019. Retrieved from https://roserbatlle.net/aprendizaje-servicio/ 
[4] M.A. Carabal Montagud, V. Santamarina Campos, J.M. Taroncher Ballestero, M. de-Miguel Molina, "Reality Baths as a Pedagogical Strategy in University Education", 12th International Technology, Education and Development Conference (INTED), pp. 2020-2027. 2018.

[5] Universitat Politècnica de València, "Competencias Transversales", 2019. Retrieved from http://www.upv.es/contenidos/COMPTRAN/index-en.html.

[6] M. de-Miguel-Molina, A. Peiró Signes, B. de Miguel Molina, M.V. Segarra-Oña, "Application of experiential learning in the development of cross-disciplinary competence in ethical, environmental and professional responsibility", 10th International Conference of Education, Research and Innovation (ICERI), pp. 2945-2949. 2017.

[7] United Nations, "Sustainable Development Goals", 2019. Retrieved from https://www.un.org/sustainabledevelopment/.

[8] S. Wu-Pong, J. Gobburu, S. O'Barr, K. Shah, J. Huber, D. Weiner, "The Future of the Pharmaceutical Sciences and Graduate Education: Recommendations from the AACP Graduate Education Special Interest Group", American Journal of Pharmaceutical Education, vol. 77, no. 4, 2013.

[9] G.A. Boy, "From STEM to STEAM: toward a human-centred education, creativity \& learning thinking", Proceedings of the 31st European conference on cognitive ergonomics, pp. 1-7. 2013. 